\title{
From the desk of Editor-in-Chief
}

doi: http://dx.doi.org/10.3329/jemc.v6i2.27758

Alhamdulillah! We are already in the $6^{\text {th }}$ year of successful publication of Journal of Enam Medical College and the journal is indexed in more than a dozen indexing databases. We share this success with the contributors, reviewers and faculties and authority of the college without whose active and sincere cooperation it would not have been possible to publish the journal regularly and timely.

The flow of paper submission for publication in the Journal of Enam Medical College continues to be very good. Papers are flowing from both home and abroad. This has been because of the quality of the journal and regular and timely publication.

In this issue we have published an important editorial titled 'Authorship in Scientific Papers'. We hope that it will be helpful for our young as well as veteran researchers willing to publish their research outcomes. It is not ethical to enlist or to be enlisted as co-authors in a research article without having substantial contribution in the research work. Those who just helped with the experiments, commented on the protocol or manuscript or helped in collection of data etc. can be acknowledged. In the editorial we have thoroughly discussed the criteria for being an author. We hope that authors of scientific papers will follow these. Let us always remember that fairness in writing influences the image of researchers and earns respect and credibility for their work.

With all the best wishes.

\section{Prof. Md. Aminul Haque Khan}

Editor-in-Chief 